\title{
PENGEMBANGAN PERANGKAT PEMBELAJARAN DENGAN MODEL SIKLUS BELAJAR HIPOTETIK DEDUKTIF UNTUK MENINGKATKAN PENGUASAAN KONSEP SISWA PADA MATERI LARUTAN ASAM BASA DI SMA
}

\author{
Wihdati Suryani ${ }^{1)}$, Suyatno $^{2)}$, Erman $^{3)}$ \\ ${ }^{1)}$ Mahasiswa Program Studi Pendidikan Sains, Program Pascasarjana Universitas Negeri Surabaya \\ ${ }^{2), 3)}$ Dosen Pascasarjana Prodi Pendidikan Sains Universitas Negeri Surabaya \\ E-mail: datiesuryani@yahoo.co.id
}

\begin{abstract}
Abstrak: Penelitian ini bertujuan untuk menghasilkan perangkat pembelajaran dengan model siklus belajar hipotetik deduktif pada materi larutan asam basa yang layak untuk meningkatkan penguasaan konsep. Pengembangan perangkat pembelajaran ini menggunakan model Research \&Development (R\&D). Perangkat pembelajaran yang dikembangkan terdiri dari RPP, BAS, LKS, dan tes penguasaan konsep. Perangkat pembelajaran di uji cobakan terhadap siswa kelas XI SMA Muhammadiyah 5 Gresik pada semester ganjil tahun ajaran 2015/2016. Rancangan uji coba menggunakan One Group Pre-test and Post-test Design. Hasil penelitian menunjukkan bahwa (1) Validitas perangkat pembelajaran masing-masing memperoleh kriteria sangat valid/valid; (2) Kepraktisan perangkat pembelajaran dilihat dari keterlaksanaan RPP mendapat kriteria baik dengan rata-rata 3,48, keterbacaan BAS mendapat nilai rata-rata tingkat keterbacaan sebesar 58\% sehingga tingkat keterbacaannya materi tepat untuk pembelajaran, aktivitas siswa mengalami peningkatan ke arah pembelajaran yang berpusat pada siswa; dan (3) keefektifan perangkat pembelajaran yang terdiri dari respon siswa mendapat respon positif dari siswa sehingga siswa merasa tertarik pada proses pembelajaran menggunakan model siklus belajar hipotetik deduktif, skor peningkatan penguasaan konsep siswa, rata-rata nilai $n$ gain sebesar 0,71 dengan kategori sedang. Berdasarkan hasil analisis data dan pembahasan diperoleh kesimpulan bahwa perangkat pembelajaran dengan model siklus belajar hipotetik deduktif layak digunakan dalam pembelajaran
\end{abstract}

\section{Kata kunci: Larutan Asam Basa, Model Siklus Belajar Hipotetik Deduktif, Penguasaan Konsep}

\begin{abstract}
This study purposed to produce a teaching materials with hypothetical deductive learning cycle model in the material acid solution decent base to improve the mastery of concepts. Development of the teaching materials using the Research \& Development (R \& D). The teaching materials developed consisting of lesson plan, student's book, worksheets and test of concept mastery. The teaching materials were tested to the students of class XI SMA Muhammadiyah 5 Gresik in the first semester of the academic year 2015/2016. The design of trials using One Group Pre-test and Post-test Design. The results showed that (1) The validity of the teaching materials respectively acquire the criteria very valid; (2) Practicality teaching materials seen from feasibility study learning implementation lesson plan got practice criteria with an average of 3.48, legibility student's book scored an average legibility level of $58 \%$ so that the legibility level appropriate teaching materials, student activity increased toward centered learning on students; and (3) the effectiveness of the teaching materials that consists of responses students received a positive response from the students so that students feel interested in learning process using hypothetical deductive learning cycle model, score improvement of students' concepts mastery, the average value of n-gain by 0.71 by category high. Based on the analysis of data and discussion is concluded that the learning device with hypothetical deductive learning cycle model feasible for use in learning process.
\end{abstract}

Keywords: Acids and Bases, Hypothetical Deductive Learning Cycle Model, Mastery of Concepts

\section{PENDAHULUAN}

Perkembangan sains dan teknologi dewasa ini berkembang sangat cepat, hal ini tentunya memerlukan daya dukung sumber daya manusia yang berkualitas. Kualitas sumber daya manusia Indonesia tahun 2012 berada di bawah sumber daya manusia Negara ASEAN lainnya yaitu Indonesia menempati peringkat ke-121, di bawah Singapura yang menempati peringkat ke-19,
Brunei Darussalam di peringkat ke-30, Malaysia di peringkat ke-65, Thailand diperingkat ke 103, dan Filipina di peringkat ke-114. Salah satu aspek pendidikan yang memiliki peran penting dalam peningkatan kualitas sumber daya manusia yaitu pendidikan sains. Keterkaitan sains dengan sumber daya manusia tidak dapat dipisahkan satu sama lain. Pendidikan sains mempunyai potensi besar untuk 
memainkan peran strategis dalam menyiapkan sumber daya manusia untuk menghadapi era industralisasi dan globalisasi, dapat menguasai dan menerapkan teknologi dengan baik. Adanya pendidikan sains yang berkualitas akan berpengaruh terhadap meningkatnya kualitas sumber daya manusia, yaitu manusia yang mampu berpikir kritis, kreatif, mampu mengaplikasikan ilmu pengetahuan dalam kehidupan, serta mampu menguasai konsep-konsep sains dengan baik (Maryati, 2007).

Kimia merupakan bagian dari sains, tujuan pengajaran kimia di SMA/MA adalah peserta didik dapat memahami konsep, prinsip, hukum, teori kimia serta saling keterkaitannya dan penerapannya untuk menyelesaikan masalah dalam kehidupan sehari-hari dan teknologi. Dengan mempelajari kimia diharapkan dapat meningkatkan sumber daya manusia. Akan tetapi, di lapangan mata pelajaran kimia sering dianggap sebagai mata pelajaran yang sulit oleh siswa. Siswa tidak bisa mengenali konsep-konsep kunci atau hubungan antar konsep yang diperlukan untuk memahami konsep-konsep tersebut, sehingga siswa tidak dapat membangun konsep-konsep kimia yang fundamental pada awal mereka belajar kimia, hal ini mengakibatkan hasil belajar kimia siswa menjadi rendah (Melati, 2012).

Materi asam basa merupakan bagian dari materi yang dipelajari di kimia. Materi asam basa sering dianggap sulit pada tingkat SMA karena materi asam basa melibatkan pemahaman banyak materi lain yaitu stoikiometri, sifat materi, kesetimbangan, dan reaksi kimia, sehingga membutuhkan pemahaman siswa. Materi asam basa yang dipelajari mencakup teori asam basa dan perhitungan $\mathrm{pH}$ larutan, sehingga materi pokok asam basa ini bersifat hafalan, hitungan, dan membutuhkan pemahaman konsep yang kuat. Pada materi asam basa yang sering menjadi kesulitan siswa adalah tentang $\mathrm{pH}$, deskripsi teoritis asam basa, dan kekuatan asam basa serta sebagian besar siswa tidak dapat menghubungkan konsep larutan dengan yang ada di sekitarnya sehingga siswa sering mempelajari materi asam basa dengan cara menghafal (Sheppard, 2006).

Masalah yang banyak dihadapi pada saat ini adalah (1) proses pembelajaran selama ini masih mengutamakan proses menghafal tanpa adanya pemahaman dan pengaplikasian konsep yang telah dipelajari; (2) siswa mampu menghafal konsep-konsep dalam sains, tetapi ketika berhadapan dengan masalah di kehidupan sehari-hari yang memerlukan penerapan sains, siswa tidak mampu mengaplikasikannya untuk memecahkan masalah; dan (3) siswa memiliki banyak pengetahuan, tetapi kurang dilatih untuk menemukan pengetahuan, konsep, dan menerapkan ilmu pengetahuan (Taufiq, 2012).

Salah satu model dan perangkat pembelajaran yang dapat digunakan untuk meningkatkan penguasaan konsep terutama pada materi larutan asam basa yaitu model siklus belajar hipotetik deduktif. Model siklus belajar menggunakan pandangan konstruktivisme yang menuntun siswa memulai proses pembelajaran dengan pertanyaan "mengapa".

Kelebihan model siklus belajar hipotetik deduktif diantaranya: 1) memberikan peluang kepada siswa untuk mengkonstruksi pengetahuan sendiri dan beraktivitas ilmiah seperti pengamatan, 2) dapat mengembangkan konsep diri siswa, dan tingkat pengharapan sehingga dapat menghindari siswa dari cara-cara belajar dengan menghafal, dan 3) memberikan waktu pada siswa untuk mengasimilasi dan mengakomodasi informasi, sehingga dari beberapa kelebihan siklus belajar hipotetik deduktif diharapkan dapat meningkatkan penguasaan konsep siswa dan membuat siswa menjadi lebih kritis, kreatif, dan berani menyampaikan pendapat (Rokhim, 2012).

Model siklus belajar hipotetik deduktif, dapat memberikan kesempatan kepada siswa untuk melibatkan pengalaman fisik, interaksi sosial, dan regulasi sendiri dalam belajar. Penggunaan model siklus belajar hipotetik deduktif dapat menciptakan pengalaman-pengalaman belajar yang berperan dalam pembentukan konsep. Pengalaman-pengalaman ini membantu siswa menemukan jawaban-jawaban atas pertanyaan-pertanyaan yang muncul selama dari tahap eksplorasi dan pengenalan konsep. Penerapan konsep penting bagi siswa untuk memperluas penerapan konsep baru, tanpa adanya berbagai variasi penerapan konsep, makna konsep itu akan terbatas pada contoh yang dibicarakan saja.

Model siklus belajar hipotetik deduktif didukung oleh beberapa teori pembelajaran, di antaranya adalah teori Piaget, Vygotsky, dan pemrosesan informasi. Pengetahuan awal yang diberikan oleh guru merupakan timbulnya skema sehingga siswa berkesempatan mengkonstruksi pengetahuan sendiri dengan merancang dan mnguji hipotesis sehingga pada tahap asimilasi Piaget. Pengetahuan yang dikonstruk oleh siswa akan membawa mereka pada tahap pengolahan informasi dalam memori jangka pendek. dan didukung oleh teori Vygotsky yaitu adanya interaksi kelompok dalam menyelesaikan masalah sehingga timbul scaffolding.

Tujuan dari penelitian ini adalah untuk menghasilkan perangkat pembelajaran dengan model siklus belajar hipotetik deduktif pada materi larutan asam basa yang layak untuk meningkatkan penguasaan konsep siswa. Kelayakan perangkat pembelajaran meliputi validitas perangkat pembelajaran, kepraktisan perangkat pembelajaran yang ditinjau dari keterlaksanaan pembelajaran menggunakan perangkat model siklus belajar hipotetik deduktif pada materi asam basa, keterbacaan buku ajar siswa, dan aktivitas siswa selama pembelajaran berlangsung. Keefektifan 
perangkat pembelajaran ditinjau dari penguasaan konsep siswa, respon siswa terhadap pembelajaran, dan kendala-kendala yang ada dalam proses pembelajaran berlangsung.

Penelitian terhadap pembelajaran model siklus belajar, yang didasarkan pendekatan konstruktivisme telah banyak dilakukan oleh para peneliti sebelumnya, diantaranya oleh Khairunnah (2014) bahwa implementasi pembelajaran kimia menggunakan model siklus belajar hipotetik deduktif pada materi larutan penyangga dapat meningkatkan penguasaan konsep dan keterampilan berpikir kreatif siswa. Senar (2012) juga menyimpulkan bahwa terdapat peningkatan yang signifikan dalam tingkat pemahaman materi dan tingkat berfikirnya antara sebelum menggunakan model pembelajaran siklus belajar hipotetik deduktif dan setelah menggunakan model tersebut. Qarareh (2012) juga menemukan adanya perbedaan yang signifikan pada pencapaian akademik kelas eksperimen yang belajar sains menggunakan model siklus belajar ini dibandingkan dengan kelas kontrol yang belajar menggunakan metode tradisional (berpusat pada guru). Lawson (2001) menyatakan bahwa siklus belajar hipotetik deduktif dapat membantu siswa untuk mengkonstruk pengetahuan dan dapat membuat siswa lebih mudah dalam mempelajari konsep yang dipelajari.

\section{METODE PENELITIAN}

Jenis penelitian ini adalah penelitian pengembangan karena dikembangkan perangkat pembelajaran kimia mengggunakan model siklus belajar hipotetik deduktif untuk meningkatkan penguasaan konsep siswa. Perangkat yang dikembangkan terdiri dari Rencana Pelaksanaan Pembelajaran (RPP), buku ajar siswa, lembar kegiatan siswa, dan lembar penilaian. subyek penelitian adalah perangkat pembelajaran kimia yang telah dikembangkan yaitu RPP, BAS, LKS dan lembar penilaian, dan diterapkan pada 25 siswa kelas XI SMA Muhammadiyah 5 Dukun Gresik tahun ajaran 2015/2016. Penelitian ini dilaksanakan dalam tiga tahap yaitu pendahuluan, pengembangan perangkat, dan evaluasi.

Teknik Pengumpulan data yang digunakan dapat digolongkan menjad: (1) validasi pakar, (2) observasi, (3) tes, dan (4) metode angket. Data-data yang telah terkumpul kemudian dilakukan analisis secara kuantitatif. Data validitas perangkat pembelajaran dihitung melalui rata-rata, sedangkan data keterlaksanaan RPP, aktivitas siswa dan keterbacaan buku ajar dihitung melalui persentase. Data hasil belajar siswa dianalisis sesuai permendikbud No. 104 tentang pedoman penilaian hasil belajar.

\section{HASIL PENELITIAN DAN DISKUSI}

\section{A. Validitas Perangkat Pembelajaran}

Hasil validasi rata-rata dari ketiga validator terhadap perangkat pembelajaran yang meliputi RPP, BAS, LKS, tes penguasaan konsep, dan lembar penilaian dapat dilihat pada Tabel 1.

Tabel 1. Hasil Validasi Perangkat Pembelajaran

\begin{tabular}{|l|l|l|l|}
\hline No & Perangkat & $\begin{array}{l}\text { Nilai } \\
\text { Validasi }\end{array}$ & Kategori \\
\hline 1 & RPP & 3,70 & Sangat valid \\
\hline 2 & BAS & 3,50 & Valid \\
\hline 3 & LKS & 3,72 & Sangat valid \\
\hline 4 & Tes penguasaan & 3,76 & Sangat valid \\
\hline
\end{tabular}

Berdasarkan validasi yang telah dilakukan oleh validator, maka perangkat pembelajaran dapat digunakan dengan melakukan revisi sesuai dengan saran dan masukan dari validator, sehingga perangkat pembelajaran ini dapat digunakan oleh guru sebagai panduan dalam proses pembelajaran.

\section{B. Keterbacaan buku Ajar Siswa}

Tingkat keterbacaan buku ajar siswa ditentukan dengan menggunakan Close Prosedure yang diberikan kepada 25 siswa yang terlibat dalam penelitian ini. Siswa diminta untuk melengkapi kalimat yang telah dihilangkan pada BAS. Hasil perhitungan keterbacaan buku ajar siswa disajikan pada Tabel 2.

Tabel 2. Keterbacaan Buku Ajar Siswa

\begin{tabular}{|c|c|c|c|}
\hline Siswa & $\begin{array}{l}\text { \% } \\
\text { Keterbacaan }\end{array}$ & Tingkat & $\begin{array}{l}\text { Siswa } \\
\text { Keterbacaan }\end{array}$ \\
\hline 1 & 48 & 14 & 61 \\
\hline 2 & 61 & 15 & 76 \\
\hline 3 & 61 & 16 & 58 \\
\hline 4 & 61 & 17 & 52 \\
\hline 5 & 61 & 18 & 61 \\
\hline 6 & 61 & 19 & 58 \\
\hline 7 & 67 & 20 & 61 \\
\hline 8 & 70 & 21 & 55 \\
\hline 9 & 61 & 22 & 61 \\
\hline 10 & 61 & 23 & 45 \\
\hline 11 & 55 & 24 & 45 \\
\hline 12 & 45 & 25 & 55 \\
\hline 13 & 61 & & 58 \\
\hline \multicolumn{3}{|c|}{ Rata-rata } \\
\hline
\end{tabular}

Berdasarkan hasil analisis data, sebagian besar siswa mengalami kemudahan dalam memahami tampilan dan isi yang terdapat di buku aja, siswa memahami uraian materi/penjelasan yang terdapat di buku ajar. Buku ajar dikatakan memiliki tingkat keterbacaan tinggi yaitu buku ajar yang mengandung panjang kalimat dan struktur kalimat sesuai pembacanya (Akbar, 2013), sehingga memudahkan siswa dalam memahami materi yang terdapat pada buku ajar dan dapat meningkatkan motivasi siswa untuk belajar. 


\section{Keterlaksanaan \\ Rencana \\ Pelaksanaan \\ Pembelajaran}

Keterlaksanaan kegiatan pembelajaran merupakan kegiatan yang mengarahkan siswa agar terlibat aktif dalam kegiatan belajar mengajar, sehingga dominasi guru berkurang dan pembelajaran berpusat pada siswa. Pengamatan terhadap keterlaksanaa RPP dalam proses pembelajaran dilakukan dengan menggunakan instrument lembar pengamatan keterlaksanaan RPP.

Ketiga fase dari model siklus belajar hipotetik deuktif yaitu fase eksplorasi, pengenalan konsep, dan aplikasi konsep membuat siswa bekerja lebih aktif daripada guru dan lebih berinteraksi dengan teman sebaya, karena menurut Vygotsky (Woolfolk, 2009) pembelajaran terjadi melalui interaksi sosial antara siswa dengan guru dan teman sebaya yang lebih mampu. Peran guru dalam pembelajaran hanya memonitor kegiatan diskusi kelompok dan memberi umpan balik dalam kegiatan presentasi. Guru hanya menjadi fasilitator bagi siswa yang belum memhami materi. Guru dapat memberi siswa anak tangga yang membawa siswa ke pemahaman yang lebih tinggi dengan catatan siswa sendiri yang memanjat anak tangga tersebut (Nur, 2008). Haail pengamatan keterlaksanaan RPP dapat dilihat pada Tabel 3.

Tabel 3. Keterlaksanaan RPP

\begin{tabular}{|l|l|c|c|}
\hline No & Aspek Penilaian & $\begin{array}{l}\text { Skor Rata- } \\
\text { rata }\end{array}$ & Kriteria \\
\hline 1 & Pendahuluan & 3,77 & Sangat Baik \\
\hline 2 & Kegiatan Inti & 3,45 & Baik \\
\cline { 2 - 4 } & Eksplorasi & 3,47 & Baik \\
\cline { 2 - 4 } & Pengenalan Konsep & 3,45 & Baik \\
\cline { 2 - 4 } & Aplikasi Konsep & 3,44 & Baik \\
\hline 3 & Penutup & 2,78 & Baik \\
\hline 4 & $\begin{array}{l}\text { Pengelolaan Kelas } \\
\text { dan Waktu }\end{array}$ & 3,40 & Baik \\
\hline \multicolumn{2}{|l|}{ Rata-rata } & $\mathbf{3 , 3 5}$ & Baik \\
\hline
\end{tabular}

\section{Aktivitas Siswa}

Data aktivitas siswa dikumpulkan melalui kegiatan pengamatan yang dilakukan oleh 2 orang pengamat menggunakan instrument lembar pengamatan aktivitas siswa. Pengamatan dilakukan setiap periode 3 menit dengan menilai aktivitas dominan dalam periode 3 menit tersebut.
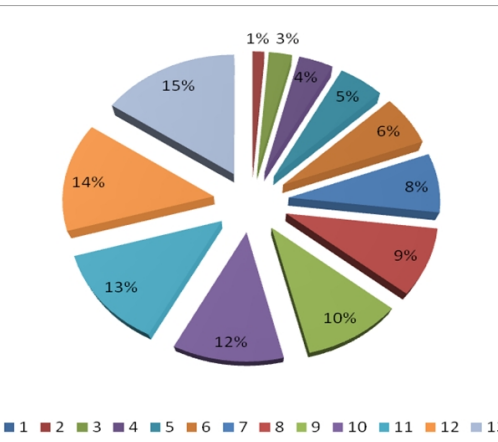

Gambar 1. Data Aktivitas Siswa
Keterangan:

1 = Memperhatikan penjelasan guru pada awal pembelajaran

2 = Mengamati fenomena yang terdapat di LKS dan membuat pertanyaan

3 = Menggali informasi yang terdapat pada sumber belajar

$4=$ Merancang dan Melakukan percobaan

$5=$ Mengamati hasil percobaan

$6=$ Bekerjasama dengan teman sekelompok

$7=$ Berdiskusi dengan teman sekelompok

$8=$ Mengkomunikasikan hasil diskusi di depan kelas

$9=$ Menyampaikan pendapat

$10=$ Membuat kesimpulan

$11=$ Mengerjakan soal aplikasi konsep

12 = Berperilaku yang tidak relevan selama KBM berlangsung, seperti berbicara selain masalah pelajaran, bermain HP, menganggu teman.

Hasil observasi aktivitas siswa membuktikan bahwa model siklus belajar hipotetik deduktif dapat meningkatkan dominasi aktivitas siswa selama proses pembelajaran. Hal ini sesuai dengan teori konstruktivis yang menyatakan bahwa proses pembelajaran harus berpusat pada siswa dan fungsi guru hanya sebagai fasilitator yang berfungsi sebagai scaffolding dari teori Vygotsky, menyatakan bahwa guru memberikan bantuan kepada anak dalam menyelesaikan masalahnya dan mengurangi bantuan setelah anak dapat melakukannya dan memiliki pengetahuan yang kuat (Santrock, 2009).

Berdasarkan hasil penelitian di atas, maka dalam pengembangan perangkat pembelajaran ini terdapat aktivitas siswa yang sangat baik dan dominan yang dapat meningkatkan penguasaan konsep siswa dan dapat mencapai tujuan pembelajaran itu sendiri. Menurut Febrika(2010), bahwa adanya aktivitas siswa dalam suatu proses pembelajaran dibuktikan dengan beberapa indikator aktivitas siswa yaitu: (1) turut serta melakukan tugas belajarnya, (2) terlibat dalam pemecahan masalah, (3) bertanya kepada siswa lain atau guru, (4) berusaha mencari berbagai informasi, (5) Melakasanakan diskusi kelompok sesuai petunjuk guru, (6) Melatih diri dalam mengerjakan soal, dan (7) Memanfaatkan kesempatan menerapkan apa yang telah diperolehnya dalam menyelesaikan tugas-tugas atau persoalan yang dihadapinya.

\section{E. Respon Siswa}

Respon siswa terhadap komponen-komponen kegiatan pembelajaran siklus belajar hipotetik deduktif dikumpulkan melalui angket respon siswa. Persentase respon siswa yang terangkum dalam Gambar ini adalah rekapitulasi rata-rata respon siswa yang diperoleh dalam tiga kali kegiatan pembelajaran yang menggunakan perangkat pembelajaran dengan model siklus belajar hipotetik deduktif. 


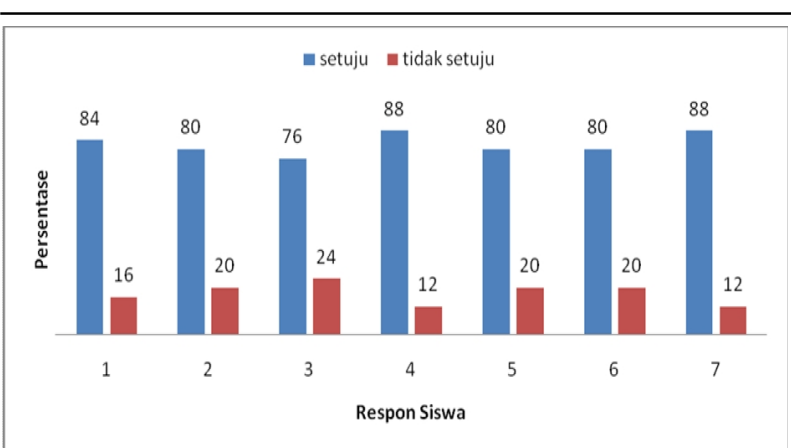

Gambar 2. Data Respon Siswa

Keterangan:

$1=$ Siswa lebih senang belajar dengan mengaplikasikan pelajaran atau materi yang didapat

$2=$ Siswa lebih berani mengemukakan pendapat dan lebih cepat paham

$3=$ Siswa lebih aktif dalam kegiatan pembelajaran

$4=$ Siswa lebih termotivasi belajar

$5=$ Siswa lebih mudah mengerjakan soal-soal

$6=$ Model siklus belajar hipotetik deduktif dengan metode eksperimen menarik dan tidak membosankan

$7=$ Model siklus belajar hipotetik deduktif dapat meningkatkan penguasaan konsep siswa

Respon positif tersebut menunjukkan bahwa siswa mengalami kemudahan dalam menerima dengan baik semua komponen yang terdapat dalam proses pembelajaran, sehingga adanya respon yang baik tersebut harapan dalam mencapai keberhasilan dalam pengajaran menjadi lebih tinggi.

\section{F. Penguasaan Konsep}

Ketuntasan individual diukur berdasarkan hasil belajar siswa yaitu tes penguasaan konsep siswa (Pretest dan posttest).

Tabel 4. Hasil Ketuntasan Penguasaan Konsep

\begin{tabular}{|l|c|c|l|l|c|c|}
\hline \multirow{2}{*}{ No } & \multicolumn{3}{|l|}{$\begin{array}{l}\text { Ketuntasan } \\
\text { Pretest }\end{array}$} & & \multicolumn{2}{l|}{$\begin{array}{l}\text { Ketuntasan siswa } \\
\text { Posttest }\end{array}$} \\
\cline { 2 - 7 } & Nilai & Predikat & Ket & Nilai & Predikat & Ket \\
\hline 1 & 1,85 & C & TT & 3,54 & A- & T \\
\hline 2 & 1,85 & C & TT & 3,38 & B + & T \\
\hline 3 & 1,69 & C- & TT & 3,08 & B & T \\
\hline 4 & 1,38 & D+ & TT & 3,54 & A- & T \\
\hline 5 & 1,85 & C & TT & 3,08 & B & T \\
\hline 6 & 2,00 & C & TT & 3,38 & B+ & T \\
\hline 7 & 1,69 & C- & TT & 3,54 & A- & T \\
\hline 8 & 1,85 & C & TT & 3,38 & B+ & T \\
\hline 9 & 1,85 & C & TT & 3,23 & B+ & T \\
\hline 10 & 1,54 & C- & TT & 3,54 & A- & T \\
\hline 11 & 1,85 & C & TT & 3,38 & B+ & T \\
\hline 12 & 1,38 & D+ & TT & 2,77 & B & T \\
\hline 13 & 1,69 & C- & TT & 3,54 & A- & T \\
\hline 14 & 1,85 & C & TT & 3,54 & A- & T \\
\hline 15 & 2,15 & C & TT & 3,69 & A- & T \\
\hline
\end{tabular}

\begin{tabular}{|l|l|l|l|l|l|l|}
\hline 16 & 2,00 & C & TT & 3,08 & B & T \\
\hline 17 & 2,15 & C & TT & 3,54 & A- & T \\
\hline 18 & 1,69 & C- & TT & 3,23 & B & T \\
\hline 19 & 2,00 & C & TT & 3,38 & A- & T \\
\hline 20 & 1,54 & C- & TT & 3,69 & A- & T \\
\hline 21 & 1,85 & C & TT & 3,54 & A- & T \\
\hline 22 & 1,85 & C & TT & 3,23 & B & T \\
\hline 23 & 2,00 & C & TT & 3,08 & B & T \\
\hline 24 & 1,85 & C & TT & 3,23 & B & T \\
\hline 25 & 1,69 & C- & TT & 3,38 & B + & T \\
\hline
\end{tabular}

Model siklus belajar hipotetik deduktif memberikan kesempatan kepada siswa untuk menerapkan pengetahuan awalnya, untuk membentuk minat dan prakarsa serta tetap menjaga keingintahuan mereka tentang topik yang dipelajari. Hal ini sesuai dengan teori Piaget yang menyatakan bahwa pengetahuan diperoleh dari tindakan (Taufiq, 2012). Keterlibatan aktif siswa dalam kegiatan pembelajaran dalam model siklus belajar hipotetik deduktif, telah membantu terjadinya proses asimilasi dan akomodasi materi larutan asam basa dalam struktur kognitif mereka.

Peningkatan penguasaan konsep siswa yang terjadi disebabkan oleh adanya pemrosesan informasi yang efektif. Gagne (1977) dengan teori pemrosesan informasinya, menegaskan bahwa informasi ditransfer secara keseluruhan dari lingkungan ke panca indera, kemudian masuk ke dalam suatu sensory register otak kita sebagai stimulus atau rangsangan

\section{G. Kendala-Kendala}

Kendala-kendala yang terjadi selama dilaksanakannya kegiatan pembelajaran perangkat pembelajaran dengan menggunakan model siklus belajar hipotetik deduktif yang diidentifikasi oleh dua orang pengamat adalah siswa belum terbiasa menggunakan model siklus belajar hipotetotik deduktif sehingga guru memberikan informasi kepada siswa tentang pembelajaran model siklus belajar hipotetik deduktif dan proses pembelajaran dan mengingatkan siswa untuk mengikuti tahap-tahap yang diarahkan sehingga membantu dalam proses pembelajaran.

Siswa belum terbiasa dalam merancang percobaan sendiri, sehingga guru memberikan bimbingan yang intensif tentang bagaimana merancang percobaan. Kurangnya bahan materi sebagai sumber belajar, maka guru memfasilitasi dengan buku jar yang dikembangkan serta membawa buku-buku kimia SMA yang lain untuk dijadikan sebagai seumber belajar.

Pada pertemuan pertama siswa merasa kurang termotivasi untuk belajar, solusi untuk mengatasi kendala tersebut adalah membangkitkan gairah semangat belajar siswa dengan memberikan beberapa pertanyaan tentang materi yang dipelajari dan 
memberikan reward bagi siswa yang mampu menjawab serta memberikan ice breaking di sela-sela pembelajaran

\section{KESIMPULAN}

\section{A. Simpulan}

Berdasarkan hasil analisis, diskusi, dan temuan dalam penelitian, maka dapat disimpulkan bahwa perangkat pembelajaran dengan model siklus belajar hipotetik deduktif sudah valid, praktis, dan efektif, sehingga layak untuk meningkatkan penguasaan konsep siswa.

\section{B. Saran}

Berdasarkan penelitian yang telah dilakukan dan hasil yang diperoleh disarankan hal-hal sebagai berikut:

1. Dalam menerapkan model pembelajaran siklus belajar hipotetik deduktif pada materi larutan asam basa guru harus mampu mengelola waktu selama pembelajaran agar pembelajaran bisa berjalan lebih efektif dan efisien.

2. Mengingat pengembangan perangkat pembelajaran dengan model siklus belajar hipotetik deduktif pada materi larutan asam basa dapat meningkatkan penguasaan konsep siswa maka diharapkan terdapat penelitian lanjutan pada materi kimia yang lain.

\section{REFERENSI}

Akbar, Sa'dun. (2013). Instrumen Perangkat Pembelajaran. Bandung: PT. Remaja Rosdakarya.

Febrika, Melzi. (2010). Peningkatan Aktivitas dan Hasil Belajar Matematika Siswa Dengan Pembelajaran Kooperatif Tipe STAD DI SMPN 17 Solok Selatan.(Tesis magister pendidikan). Universitas Negeri Padang.

Gagne, N.L., \& Berliner, D.C. (1988). Educational Psychology. Second Edition. Boston: Hougton Miff Lin Company.

Khoirunnah, N.W. (2014). Implementasi Model Siklus Belajar Hipotetikal Deduktif untuk Meningkatkan Penguasaan Konsep dan Keterampilan Berpikir Kreatif Siswa SMA pada Materi Pokok Larutan Penyangga (Tesis magister pendidikan tidak dipublikasikan). Universitas Negeri Surabaya.

Maryati. (2007). Usaha Mengatasi Problematika Pendidikan sains Di Sekolah dan Perguruan
Tinggi. Padang: Dosen Fakultas Tarbiyah IAIN Imam Bonjol Padang.

Melati. (2012). Meningkatkan Aktivitas dan hasil belajar siswa SMAN 1 Sungai Ambawang melalui pembelajaran model Advance Organizer berlatar numbered heads together (NHT) pada materi kelarutan dan hasil kali kelarutan. Jurnal Visi lmu Pendidikan.

Nur, M. (2008). Pengajaran Berpusat kepada Siswa dan Pendekatan Konstruktivis dalam Pengajaran. Surabaya; PSMS UNESA.

Qarareh, A.O. (2012). "The Effect of Using the Learning Cycle Method in Teaching Science on the Educational Achievement of the Sixth Graders". International Journal of Educational Science, Vol. 4 No. 2, pp. 123-132.

Rokhim, Fathur, Sudarisman, dan Suciati, Suparmi, (2012). "Pembelajaran Biologi Model Siklus Belajar Hipotetik Deduktif Dengan Media Rill dan Media Virtuil Ditinjau dari Kemampuan Penalaran Analitis dan Gaya Belajar Siswa”. Jurnal Inkuiri Pascasarjana Universitas Negeri Solo. Vol 1 No 2, pp 121-131.

Santrock, J. W. (2009). Psikologi Pendidikan. Jakarta: Prenada Media Group.

Senar, D. S., \& Yilmaz, A. (2012). "The Effect of Learning Cycle Model on Preservice Chemistry Teachers' Undersatnding of Oxidation Reduction Topic and Thinking Skills". Necatibey Faculty of Education.

Sheppard, Keith. 2006. High School students's understanding of Titrations and related acidbase phenomena. Educational research in Columbia university, New York.

Taufiq, W. \& Ketang. (2012). Aplikasi Model Pembelajaran Siklus Belajar Hipotetik Deduktif untuk Meningkatkan Ketrampilan Generik Sains Siswa SMA pada Materi Pokok Kesetimbangan Benda Tegar. Prosiding Seminar Internasional Pendidikan Sains UPI Bandung, halaman 641648.

Woolfolk, Anita. (2009). Educational Psychology Active Learning Edition, Edisi Kesepuluh, Bagian Kedua. Yogyakarta: Pustaka Belajar. 